\title{
NITROGEN USE EFFICIENCY OF POULTRY MANURE N BY MAIZE
}

\author{
S. A. Boateng ${ }^{1}$, M. Kornahrens ${ }^{2}$ and J. Zickermann ${ }^{2}$ \\ ${ }^{1}$ Soil Research Institute, Academy Post Office, Kwadaso-Kumasi \\ ${ }^{2}$ Formerly of University of Bayreuth, Germany.
}

\begin{abstract}
Nitrogen use efficiency is a measure of the extent to which a crop transforms available $N$ to economic yield. Poultry manure is often reported to have lower $N$ use efficiency than mineral fertilizer in the first year of application. However, under certain conditions such as rate of application, $N$ mineralization rate, type of soil and crop, the converse may be the case. Will a farmer be better off in applying poultry manure at a particular rate than mineral fertilizer? A study was conducted on a forest acrisol to determine the physiological and apparent $N$ efficiencies of poultry manure (PM) applied at various rates and mineral fertilizer to maize. Poultry manure rates of $2,4,6,8$ and $2 \times 2 t$ $h^{-1}$ (i.e. split application) showed higher physiological $N$ use efficiencies than the mineral fertilizer

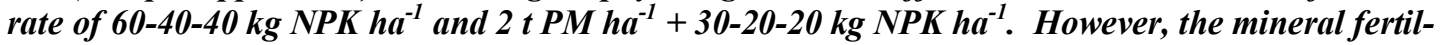
izers (including combined half rate plus 2 t poultry manure) had the highest apparent $N$ use efficiencies of $58 \%$ and $40 \%$ respectively, but low physiological $N$ use efficiency. Among the poultry manure treatments, $4 \mathrm{t} \mathrm{ha} \mathrm{a}^{-1}$ with the highest $\mathrm{N}$ content of $2.17 \%$ in the maize ear leaves and grain $N$ content of $12.56 \mathrm{~g} \mathrm{~kg}^{-1}$, had the highest physiological $\mathrm{N}$ use efficiency of $60 \mathrm{~kg} \mathrm{ha}^{-1}$ making it the most efficient rate in the transformation of $N$ into grain yield.
\end{abstract}

Keywords: poultry manure, mineral fertilizer, nitrogen use efficiency, maize

\section{INTRODUCTION}

The removal of subsidy on mineral fertilizers in Ghana has made the prices go out of reach of many farmers. This has led to reduced use that has resulted in declining soil fertility and low crop yields. Alternative sources of nutrients are being advocated for and such locally organic sources as poultry manure attract a high premium.
Poultry manure is known to contain the highest $\mathrm{N}$ content among the common farmyard sources of manure such as the dung of cattle, sheep, goat, rabbit and horse. It contains between 2.0 and 3.5\% N (Agyenim Boateng et al., 1997). A number of farmers in the southern part of Ghana have been using it as their major nutrient source. In the urban centres there is a scramble for poultry manure by vegetable growers and other horticul- 
tural farmers. Poultry manure is a valuable, more or less concentrated and quick-acting organic fertilizer. It contains all the basic nutrients necessary for crop; these nutrients being in the form of available compounds. The $\mathrm{N}$ in poultry manure is part of organic compounds, which are present in the form of uric acid. This uric acid has to be hydrolyzed to ammonium (Sims and Wolf, 1994) and/or additionally oxidized to nitrate (Edwards and Daniel, 1992) before plants can absorb for use.

The relatively high $\mathrm{N}$ availability of mineral fertilizers compared with organic manures explains the higher apparent $\mathrm{N}$ use efficiency (Bock, 1984) of the former. Sieling et al. (1998), in their studies of mineral and slurry nitrogen effects on oilseed rape, found that apparent nitrogen use efficiency of mineral $\mathrm{N}$ was larger than that of slurry $\mathrm{N}$, but decreased with increasing mineral fertilizer $\mathrm{N}$ rates. Mineralization of organically bound nitrogen in poultry manure precedes the nitrification of ammonium compounds (Siegel et al., 1975; Hadas et al., 1983).

The $\mathrm{N}$ dynamics of poultry manure depends on a wide range of factors such as properties of the poultry manure - whether wet or dry, fresh or decomposed, alone or mixed with bedding material; the soil to which it is applied - type, $\mathrm{pH}$, depth, degree of wetness; temperature range and precipitation distribution. Fischback et al. (1992), working on winter wheat reported that, in general, the $\mathrm{N}$ use efficiency of mineral $\mathrm{N}$ fertilizer by winter wheat decreases with increasing amounts of $\mathrm{N}$ and varies with a number of factors, such as year, site and preceding crop(s). Finck (1994) and Schröder (1997) noted that the $\mathrm{N}$ use efficiency of slurry $\mathrm{N}$ showed large variations depending on application date and prevailing weather conditions, and decreased with increasing amounts. It is thus, similarly, expected that $\mathrm{N}$ use efficiency of poultry manure by maize will depend on a number of factors, particularly rates of application.

In spite of the numerous research works done on maize in Ghana, studies on its $\mathrm{N}$ use efficiency regarding poultry manure application have received little attention. The objective of this study was to determine the effects of different rates of poultry manure application on yield, $\mathrm{N}$ uptake and $\mathrm{N}$ use efficiency by maize on a forest acrisol.

\section{MATERIALS AND METHODS}

Manure and soil characterization

Dry semi-decomposed poultry manure from laying hens in a deep litter system was collected from Darko Farms, a large-scale commercial poultry farm. Semi-decomposed poultry manure is the type that is easily available and commonly used by farmers on their crops. The moisture and dry matter contents of the manure were determined by drying in an oven at $70^{\circ} \mathrm{C}$ for three days. A sub-sample of the manure was then dryashed in a muffle oven $\left(550^{\circ} \mathrm{C}\right)$ for organic matter determination according to Schlichting and Blume (1966). Another sub-sample was used to determine the other properties. The $\mathrm{pH}$ was measured in water (manure:water 1:10). The $\mathrm{C}$ and $\mathrm{N}$ contents were gaschromatographically measured with an auto-analyzer (Vario EL). Available $\mathrm{P}$ and $\mathrm{K}$ were determined by the method as described by Schüller (1969) using spectrophotometric and flame photometric techniques respectively after extraction of air-dried poultry manure by $2 \mathrm{M} \mathrm{KCl}$ solution (1 part poultry manure : 25 parts $\mathrm{KCl}$ solution).

The study was conducted in 1998 and 1999 at the Arable Farm Research fields of the Kwame Nkrumah University of Science and Technology, Kumasi, in the semi-deciduous rain forest zone of Ghana with an annual rainfall of $1500-2000$ $\mathrm{mm}$. The soil was classified as Ferric Acrisol with a slope of $2-3 \%$.

The characteristics of the soil were determined before the experiment. Soil texture was determined by using the araometer method (Schachtschabel et al., 1992). The $\mathrm{pH}$ was determined potentiometrically in deionised water (1:5) and $0.01 \mathrm{M} \mathrm{CaCl}_{2}$ solution. Bulk density was determined by using iron cores in steps of 10 $\mathrm{cm}$ soil depth up to $40 \mathrm{~cm}$ and drying the soil at

74 Journal of Science and Technology, Volume 27 no. 2, August, 2007 
$105^{\circ} \mathrm{C}$ for 24 hours. The $\mathrm{C}$ and $\mathrm{N}$ contents were gaschromatographically analyzed by using an auto-analyzer (Vario EL). The organic matter content was determined by wet-ashing according to Schlichting and Blume (1966). Available P and $\mathrm{K}$ were determined by the method as described by Schüller (1969).

Both manure and soil were analyzed at the laboratory of the Institute of Soil Science, University of Bayreuth, Germany.

\section{Experimental design}

The trial consisted of eight treatments replicated five times in a randomized complete block design. Each plot measured $5.0 \mathrm{~m}$ x $6.0 \mathrm{~m}$ giving an area of $30 \mathrm{~m}^{2}$. Maize (var 'Abeleehi', a medium maturing variety) was used. The treatments and the equivalent amount of nutrients contained in each treatment are given in Table 1. The poultry manure was applied by digging small holes with the hand hoe and subsequently putting in the manure (i.e. a type of point application) six days before sowing the maize by the side of the manure. Three seeds of maize were sown per stand and were thinned to two, 14 days after planting, giving the plant density of six plants per $\mathrm{m}^{2}$. The inter-row spacing was $90 \mathrm{~cm}$ and the intra-row $40 \mathrm{~cm}$. The mineral fertilizers, 15-15-
15 NPK was applied 10 days after planting as basal and sulphate of ammonia six weeks after planting as topdress. In the case of the split application of the manure, the other half was applied at six weeks after planting.

Weeds were controlled manually with a hoe as and when necessary. The plants were allowed to grow to maturity and then manually harvested. Data for the two years were collected at silking on ear leaves and at maturity on grains and stover. The mean values for the two years data are being reported on.

\section{$\mathbf{N}$ contents of ear leaves and grains of maize}

Five ear leaves per plot were collected at silking and dried for three days at $65^{\circ} \mathrm{C}$ to determine the $\mathrm{N}$ content of maize ear leaves. The material was ground and sieved $(0.2 \mathrm{~mm})$ and analyzed for total $\mathrm{N}$ content. The ear leaves were selected because the nutrient content of ear leaf of maize at silking is found to be the best predictor of nutrient content of harvested grains (Weil and Mughogho, 2000). The $\mathrm{N}$ content of the harvested grains was also determined and used to estimate the apparent $\mathrm{N}$ and physiological $\mathrm{N}$ efficiencies. Grains were ground into a fine powder with a rolling ball mill and analyzed for total $\mathrm{N}$ by combustion on a CNS analyzer (Sieling et al.,

Table 1: Treatments and their respective amount of nutrients

\begin{tabular}{|c|c|c|}
\hline Treatments & & $\begin{array}{l}\text { Amount of nutrients } \\
\left(\mathrm{Kg} \text { N-P-K ha }{ }^{-1}\right)\end{array}$ \\
\hline Nil fertilizer or manure & Control & -- \\
\hline Two tons of poultry manure per hectare & $-\quad 2 \mathrm{tPM} \mathrm{ha}^{-1}$ & $48-25-32$ \\
\hline Four tons of poultry manure per hectare & $-\quad 4 \mathrm{t} \mathrm{PM} \mathrm{ha}^{-1}$ & $96-50-64$ \\
\hline Six tons of poultry manure per hectare & $-\quad 6 \mathrm{t} \mathrm{PM} \mathrm{ha}^{-1}$ & $144-75-96$ \\
\hline Eight tons of poultry manure per hectare & $-\quad 8 \mathrm{t} \mathrm{PM} \mathrm{ha}^{-1}$ & $192-100-128$ \\
\hline Mineral fertilizer at recommended rate & - $\quad$ NPK & $60-40-40$ \\
\hline $\begin{array}{l}\text { Two tons of poultry manure per hectare } \\
\text { plus one-half rate of mineral fertilizer }\end{array}$ & $-\quad 2 \mathrm{tPM} \mathrm{ha}^{-1}$ & NPK $78-45-52$ \\
\hline Split application of $4 \mathrm{t} \mathrm{PM} \mathrm{ha}^{-1}$ & $2 \times 2 \mathrm{t} \mathrm{PM} \mathrm{ha}^{-1}$ & $96-50-64$ \\
\hline
\end{tabular}


1998). The $\mathrm{N}$ uptake was calculated from the yield measurements and total $\mathrm{N}$ in plant parts according to the relationship by Sieling et al. (1998):

$N$ uptake (of plant parts) $=$ Total dry matter ( $\left.t \mathrm{ha}^{-1}\right) \times$ Total $N$ content (of plant parts)

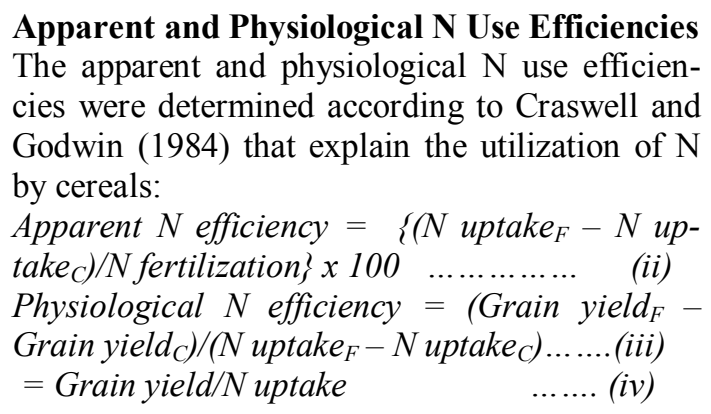

Where,

$F=$ fertilizer (organic or inorganic), and $C=$ control

The above formulae assume that all plants of any treatment make use of the $\mathrm{N}$ pool in the soil to the same extent.

\section{Yields}

Maize stover and grain yields were determined at plant maturity by harvesting and weighing 18 plants per plot and drying the stover and grains in an oven at $70^{\circ} \mathrm{C}$ for three days.

\section{Statistical Analysis}

Manure and soil data were not subjected to statistical analysis because bulked samples of treatments were taken and analyzed at the laboratory.
Crop data were statistically analyzed using MSTATC (1988) statistical package.

\section{RESULTS AND DISCUSSION \\ Properties of the soil and poultry manure}

Table 2 shows the characteristics of the soil used in the study. The soil was sandy clay, the clay contents increasing with soil depth. The ratio of silt to clay was very wide i.e. silt-clay content was very low, indicating high weathering nature of the soil and oligotrophic conditions (Pagel et al., 1982). Bulk density of the topsoil was relatively low while the values of the lower horizons were relatively high which is characteristic of common agricultural soils of the tropics. The relatively low $\mathrm{pH}$, decreasing with soil depth, is typical of ferric acrisols (Sillanpää, 1982). The soil had low contents of organic $\mathrm{C}$, total $\mathrm{N}$ and $\mathrm{P}$ (Pagel et al., 1982). In view of the kaolinitic clay minerals, the exchangeable $\mathrm{K}$ content of the soil was rather high.

Some properties of the poultry manure used in the study are shown in Table 3 . The nutrient contents were quite high and compared well with other values reported in other countries (Archer, 1985; Yagodin, 1984; Perkins and Parker, 1971). The high $\mathrm{Ca}$ content was probably responsible for the relatively high $\mathrm{pH}$. The ammonium content was, however, low.

\section{$N$ content of ear leaves and grains}

The $\mathrm{N}$ content of the ear leaves of maize during flowering is shown in Fig 1a. All the treatments indicated low amounts of $\mathrm{N}$. The $\mathrm{N}$ content of 2 t PM ha ${ }^{-1}$ rate was similar to the control, proba-

Table 2: Characterization of the soil at the experimental site

\begin{tabular}{|c|c|c|c|c|c|c|c|c|c|c|c|}
\hline $\begin{array}{l}\text { Soil depth } \\
(\mathrm{cm})\end{array}$ & $\begin{array}{l}\text { Soil t } \\
\text { sand }\end{array}$ & $\begin{array}{l}\text { exture } \\
\text { silt }\end{array}$ & $\begin{array}{l}(\%) \\
\text { clay }\end{array}$ & $\begin{array}{l}\text { Bulk density } \\
\qquad \mathrm{Mg} \mathrm{m}^{-3}\end{array}$ & $\begin{array}{c}\mathrm{pH} \\
\left(\mathrm{H}_{2} \mathrm{O}\right)\end{array}$ & Total N & $\begin{array}{c}\text { Org. C } \\
--\%\end{array}$ & Org. M & $\begin{array}{l}\mathrm{C} / \mathrm{N} \\
\text { ratio }\end{array}$ & ---- & $\begin{array}{l}\text { Avail. P Avail K } \\
\text { - } \mathrm{mg} \mathrm{kg}^{-1}----\end{array}$ \\
\hline $0-10$ & 65.3 & 7.9 & 26.8 & 1.48 & 5.7 & 0.09 & 0.98 & 1.7 & 10.7 & 26 & 11 \\
\hline $10-20$ & 63.7 & 6.9 & 29.4 & 1.57 & 5.4 & 0.07 & 0.70 & 1.2 & 10.6 & - & - \\
\hline $20-30$ & 57.4 & 5.4 & 37.2 & 1.58 & 5.3 & 0.06 & 0.56 & 1.0 & 9.4 & 12 & 7.5 \\
\hline $30-40$ & 52.6 & 4.8 & 42.6 & 1.61 & 4.9 & 0.05 & 0.53 & 0.9 & 10.6 & - & - \\
\hline
\end{tabular}

76 Journal of Science and Technology, Volume 27 no. 2, August, 2007 


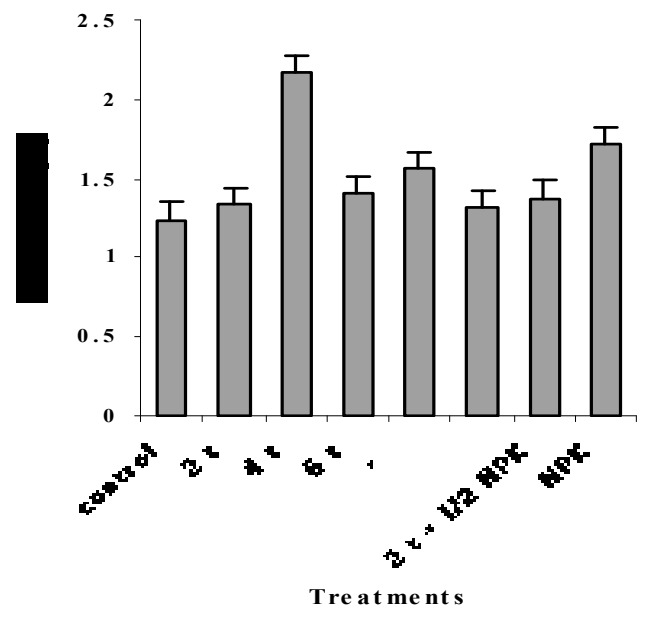

Fig 1a: Ear leaf $\mathbf{N}$ of maize at flowering

bly because of greater production of biomass (Fig 2) causing dilution of $\mathrm{N}$ in ear leaves. This may also account for the low $\mathrm{N}$ value in the ear leaves of the $8 \mathrm{t} \mathrm{PM} \mathrm{ha}^{-1}$ rate. The highest $\mathrm{N}$ contents were shown by $4 \mathrm{t} \mathrm{PM} \mathrm{ha}^{-1}$ rate, beyond which there was declining $\mathrm{N}$ supply. However, split application of $4 \mathrm{t} \mathrm{PM} \mathrm{ha-1} \mathrm{(i.e.} 2 \times 2 \mathrm{t} \mathrm{PM}$ $\mathrm{ha}^{-1}$ ) resulted in a reduction of $\mathrm{N}$ content in ear leaves probably because the additional $2 \mathrm{t}$ applied as topdress at six weeks after planting had not been mineralized to make $\mathrm{N}$ available for uptake. The application of poultry manure combined with mineral fertilizer $\left(2 \mathrm{t} \mathrm{PM} \mathrm{ha}^{-1}+1 / 2\right.$ NPK), 6t PM ha ${ }^{-1}$ and sole mineral fertilizer treatments resulted in a "medium" status of $\mathrm{N}$ supply (indicated by medium position of $\mathrm{N}$ content of ear leaves). Thus, no treatment reached the level of sufficient $\mathrm{N}$ supply of $2.70-3.20 \%$ for maize ear leaves as reported by Pagel et al. (1982).

The nitrogen content of the grains at maturity is presented in Fig 1b. The values, ranging from 12.09 to $15.17 \mathrm{~g} \mathrm{~kg}^{-1}$, increased with increasing rate of application among the poultry manure treatments. The higher manure rates $(6$ and $8 \mathrm{t}$

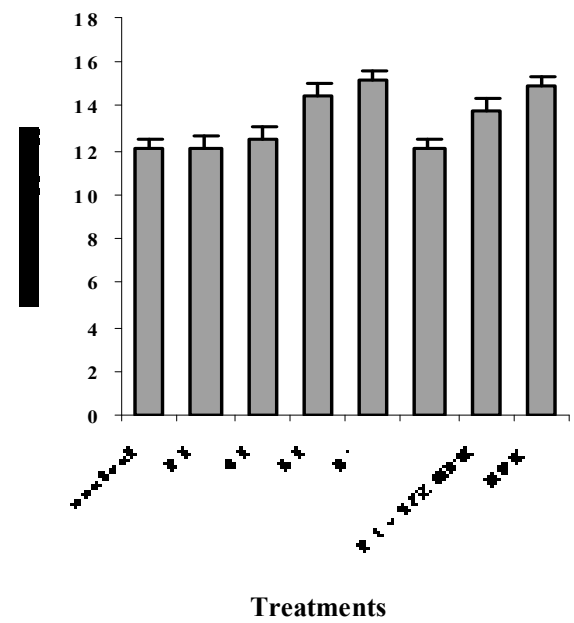

Fig 1b: Grain of Maize at Maturity

$\mathrm{ha}^{-1}$ ) and the full inorganic fertilizer rate were similar to each other indicating that these treatments did not have significant effect on the nitrogen content of maize grains. Mahimairaja et al. (1995), working on cabbage, noted that there were only small differences in $\mathrm{N}$ content between treatments. The highest value of $15.17 \mathrm{~g}$ $\mathrm{kg}^{-1}$ was reached by the $8 \mathrm{t} \mathrm{pm} \mathrm{ha}{ }^{-1}$ followed closely by the full NPK treatment. Mahimairaja et al. (1995), however, reported that the inorganic fertilizer treatment resulted in the highest $\mathrm{N}$ content among manure treatments on cabbage.

\section{Biomass and Grain Yields}

The biomass and grain yields of the crop are presented in Fig 2. The $6 \mathrm{t}$ and $8 \mathrm{t} \mathrm{pm} / \mathrm{ha}$ rates produced higher biomass and grain yields than the NPK fertilizer probably as a result of the enhancement of good physical properties of the soil by the organic manure in addition to the nutrients release. The other treatments followed the trend of the $\mathrm{N}$ content of the ear leaves as presented in Fig 1a, thus agreeing with the observation made by Loecke et al. (2004) that grain yield of maize is closely related to the $\mathrm{N}$ uptake in times of adequate water supply. Mahimairaja et al. (1995) also observed a linear increase in yield with in- 


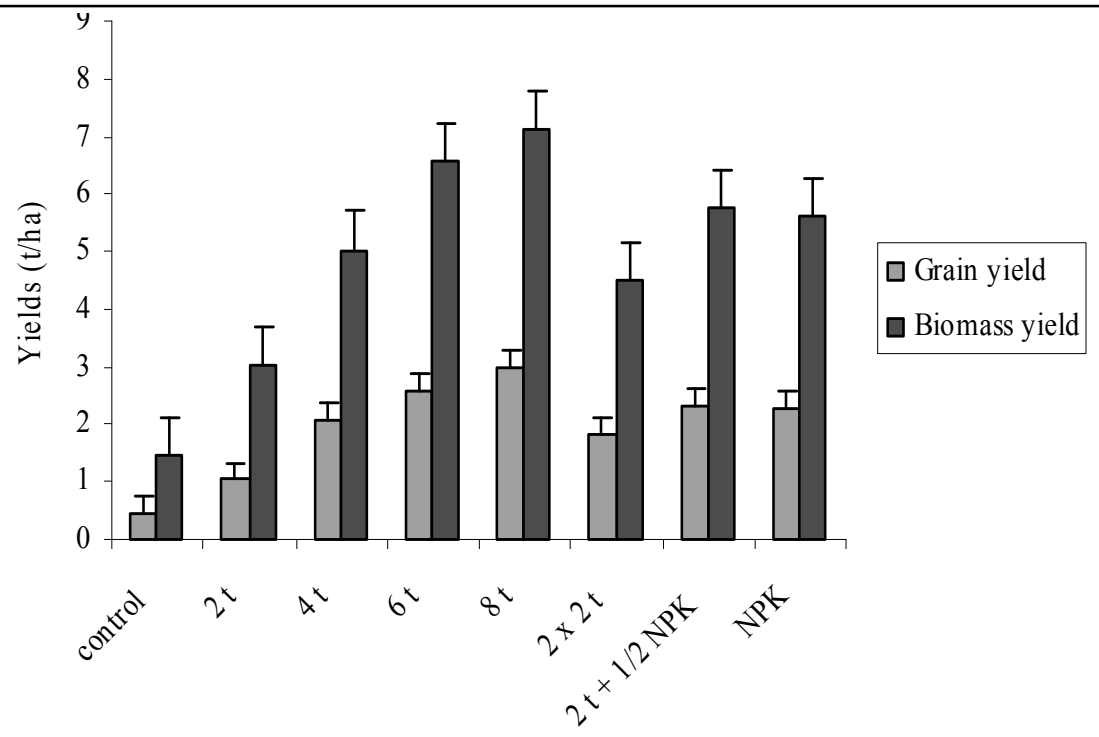

Treatments

Fig. 2: Biomass and grain yields of maize

Table 3: Nutrient contents of the poultry manure

\begin{tabular}{|c|c|c|}
\hline Parameter & Content & Reported Range* \\
\hline Total N, \% & 2.42 & $2.17-3.50$ \\
\hline $\mathrm{NH}_{4}^{+}, \%$ & 0.12 & --- \\
\hline $\mathrm{P}_{2} \mathrm{O}_{5}, \%$ & 1.23 & $0.18-1.68$ \\
\hline $\mathrm{K}_{2} \mathrm{O}, \%$ & 1.62 & $0.90-2.17$ \\
\hline $\mathrm{Ca}, \%$ & 3.35 & $1.28-4.40$ \\
\hline $\mathrm{Mg}, \%$ & 2.15 & $1.54-4.70$ \\
\hline Org. C, \% & 35.30 & $26.30-40.69$ \\
\hline Organic Matter, \% & 61.90 & $45 .-39-70.15$ \\
\hline $\mathrm{C} / \mathrm{N}$ ratio & 14.60 & $11.3-13.8$ \\
\hline $\mathrm{pH}\left(\mathrm{H}_{2} \mathrm{O}\right)$ & 7.70 & $6.8-8.4$ \\
\hline Moisture content, $\%$ & 11.40 & --- \\
\hline
\end{tabular}

creasing $\mathrm{N}$ content in cabbage. Generally, in this study biomass and grain yields followed the same trend.

Apparent and physiological $\mathbf{N}$ use efficiencies Nitrogen use efficiency is a measure of the extent to which a crop transforms available $\mathrm{N}$ to economic yield (Ma et al., 1999). Mineral fertilizer is highly water-soluble and, therefore nutrients contained in it are most available for plants use (Oemichen, 1986). Nitrogen in poultry manure is part of organic compounds and is present in the form of uric acid. Before nitrogen in poultry manure is made available for plants, uric acid has to be hydrolyzed to ammonium and/or additionally oxidized to nitrate (Edwards and Daniel, 1992). As a result of the relatively high nutrient availability of mineral fertilizers compared with organic fertilizers, $\mathrm{N}$ fertilizers regularly achieve a greater apparent $\mathrm{N}$ efficiency, which is in the range of $50-60 \%$ (Boch, 1984). The results of this study were in agreement with this observation since a value of 58\% was achieved (Fig 3). It should, however, be noted that $\mathrm{N}$ use efficiency is generally calculated for one crop - in 
this case, maize - and not for a complete crop rotation. Thus, for a chain of crops, the apparent $\mathrm{N}$ efficiency of organic fertilizers may increase, as delays in releases of $\mathrm{N}$ may occur.

Figure 3, which shows $\mathrm{N}$ use efficiency and the $\mathrm{N}$ uptake of maize, indicates that the maximum $\mathrm{N}$ uptake was $45.5 \mathrm{~kg} \mathrm{ha}^{-1}$ from the $8 \mathrm{t} \mathrm{PM} \mathrm{ha}^{-1}$ treatment. This seems surprising since a much higher value was expected. However, in terms of a low plant density of six plants $/ \mathrm{m}^{2}$ arising from the spacing, it should be acceptable.

Although there was no difference among the poultry manure treatments (i.e. 2, 4, 6 and $8 \mathrm{t}$ PM $\mathrm{ha}^{-1}$ ) in both apparent $\mathrm{N}$ and physiological $\mathrm{N}$ use efficiencies, the $4 \mathrm{t} \mathrm{PM} \mathrm{ha}{ }^{-1}$ had the highest apparent $\mathrm{N}$ use efficiency. Thus, the transformation of $\mathrm{N}$ uptake into grain yield was most effective. The apparent $\mathrm{N}$ use efficiency showed a trend of $4 \mathrm{t}>6 \mathrm{t}>2 \times 2 \mathrm{t}>8 \mathrm{t}>2 \mathrm{t} \mathrm{PM} \mathrm{ha}^{-1}$ and the physiological $\mathrm{N}$ use efficiency followed almost a similar trend of $4 \mathrm{t}>2 \times 2 \mathrm{t}>6 \mathrm{t}>8 \mathrm{t}>2 \mathrm{t} P M$ $\mathrm{ha}^{-1}$.
Generally, increasing rates of poultry manure application showed increasing $\mathrm{N}$ uptake. However, apparent $\mathrm{N}$ use efficiency largely showed that of decreasing effect. The nitrogen applied in $2 \times 2$ t PM ha ${ }^{-1}$ rate could not be used by the plants as in $4 \mathrm{t} \mathrm{PM} \mathrm{ha}^{-1}$ rate as indicated by lower apparent $\mathrm{N}$ use efficiency. This might be due to the splitting method of application.

The apparent $\mathrm{N}$ use efficiency for $2 \mathrm{t} \mathrm{PM} \mathrm{ha}{ }^{-1}+$ $1 / 2$ NPK was about $40 \%$, and that of mineral fertilizer reached the highest value of $58 \%$ indicating high apparent $\mathrm{N}$ use efficiency of mineral fertilizers as reported by Boch (1984). There was a low trend for sole poultry manure treatments whose values were between 24 and $27 \%$. Loecke et al. (2004) reported an apparent $\mathrm{N}$ use efficiency of $17 \%$ for swine manure and $45 \%$ for the mineral fertilizer treatment by maize across a period of four years. In spite of the highest apparent $\mathrm{N}$ use efficiency of the mineral fertilizer in this study, the physiological $\mathrm{N}$ use efficiency, however, was the lowest. This implies that the

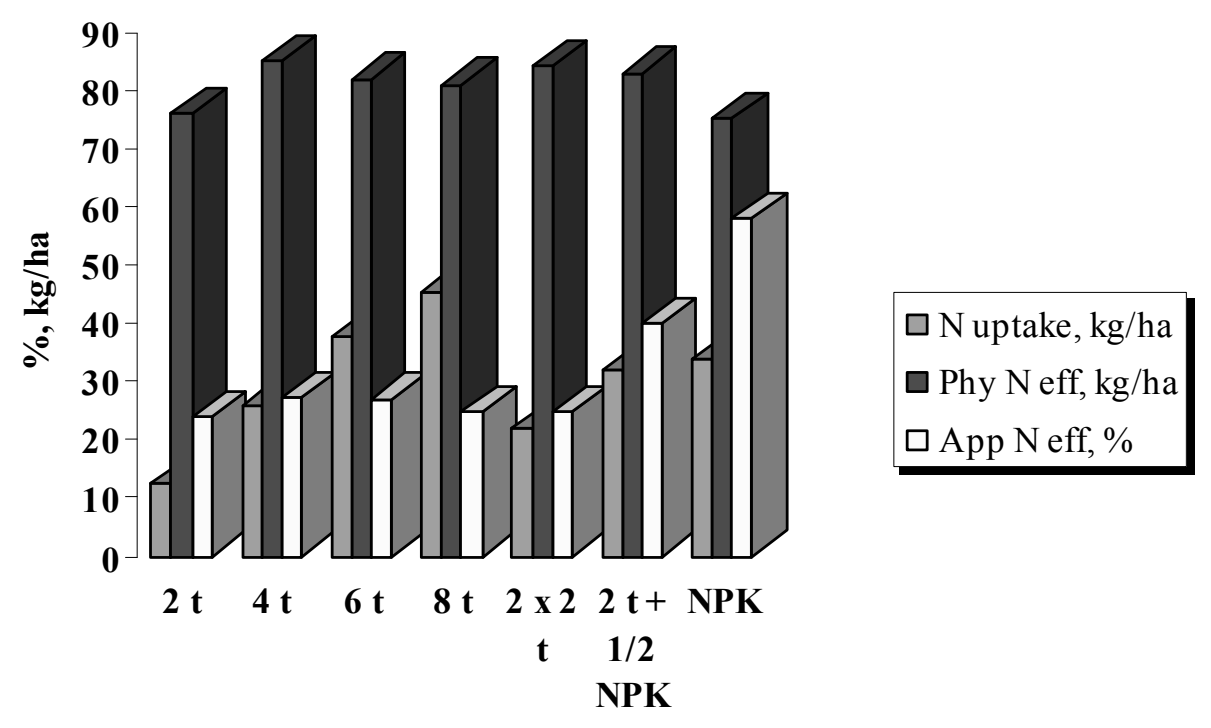

Treatments

Fig 3: $N$ use efficiencies of poultry manure by maize 
nitrogen in mineral fertilizer taken up by plants was not adequately transformed into grain yield.

The differences in the physiological $\mathrm{N}$ use efficiencies between the manure and mineral fertilizer treatments might be clarified with respect to plant nutrition and nitrogen status of maize. The analyses of the ear leaves in Fig 1a indicate that the $\mathrm{N}$ content of the plants of mineral fertilizer treatment was high $(1.72 \%)$. Although the ear leaves of $2 \mathrm{t} \mathrm{PM} \mathrm{ha}^{-1}+1 / 2$ NPK treatment showed a comparatively lower $\mathrm{N}$ content $(1.38 \%)$, its physiological $\mathrm{N}$ use efficiency surpassed that of the sole mineral fertilizer. The physiological $\mathrm{N}$ use efficiencies of the poultry manure treatments were higher than that of the sole mineral fertilizer, although the $\mathrm{N}$ contents of the ear leaves were generally relatively lower. According to Baumer (1992), physiological $\mathrm{N}$ use efficiency was at its highest value when all nutrients necessary for plant growth were present in an optimal ratio. Poultry manure satisfies this condition to some extent since it contains all the necessary plant nutrients (Yagodin, 1984), although their ratios are variable.

Loecke et al. (2004) found in their work with swine manure that ear leaf $\mathrm{N}$ concentration correlated well with maize yield. In this study, the 4 t PM ha ${ }^{-1}$ rate achieved the highest $\mathrm{N}$ supply in the ear leaves; hence it had the highest physiological $\mathrm{N}$ use efficiency although the $\mathrm{N}$ in the ear leaves indicated a supply below the limit set by Pagel et al. (1982).

\section{CONCLUSION}

The study indicates that organic manures have lower apparent $\mathrm{N}$ use efficiency than mineral fertilizers. The $4 \mathrm{t} \mathrm{PM} \mathrm{ha}{ }^{-1}$ had the highest value (25\%) among the poultry manure treatments compared with the sole mineral fertilizer and the combined mineral fertilizer plus poultry manure treatments which had 58\% and $40 \%$ apparent $\mathrm{N}$ use efficiencies respectively. However, the mineral fertilizers could not register the highest physiological $\mathrm{N}$ efficiencies. The poultry manures had the highest; the $4 \mathrm{t} \mathrm{ha}^{-1}$ being the best (about $60 \mathrm{~kg} \mathrm{~N} \mathrm{ha}^{-1}$ ). It can be said that $\mathrm{N}$ in poultry manures, once taken up by plants, are relatively better utilized into grain yield than mineral fertilizers. This is a bit surprising since this is mostly true when poultry manure is used over several seasons or years. The established result has mineral fertilizer better transforming $\mathrm{N}$ into grain mainly in the first season or year. The result of this study suggests that if a farmer is looking to obtaining maximum benefits (considering cost effect and labour) from applied fertilizer (organic or inorganic) to maize, he/she is better off applying poultry manure, particularly at the rate of $4 \mathrm{t} \mathrm{ha}^{-1}$.

\section{REFERENCES}

Agyenim Boateng, S., Kornahrens, M. and Zickemann, J. (1997). Biomass management of sustainable cropping in humid areas of tropical Africa, Report of collaborative project of University of Science and Technology, Kumasi, and IBSRAM.

Archer, J. (1985). “Crop nutrition and fertilizer use", Farming Press Ltd., Ipswich Suffolk, 124 (125): 128-130.

Baeumer, K. (1992). “Allgemeiner Pflanzenbau”, $3^{\text {rd }}$ ed. Ulmer Verlag, Stuttgart.

Bock, B.R. (1984). Efficient Use of Nitrogen in Cropping Systems. Nitrogen in Crop Production, Hauk, R.D. (Ed.), Madison, Wisconsin, USA, S. 273-294.

Craswell, E.T. and Godwin, D.C. (1984). The efficiency of nitrogen fertilizers applied to cereals in different climates, Adv. Plant Nutr. 1: $1-55$

Edwards, D.R. and Daniel, T.C. (1992). Environmental Impacts of On-Farm Poultry Waste Disposal - A Review, Bioresource Technology 42: 9-33.

Finck, M. (1994). Einflu $\beta$ der Wechselwirkungen zwischen Gulledungeng, mineralischer $N$ Dungung, Bodenbearbeitung und Fungizidbehandlung auf Wachstum, N-Aufnahme,Ertrag

80 Journal of Science and Technology, Volume 27 no. 2, August, 2007 
und $N$-Verwertung bei Winterweizen. $\mathrm{PhD}$ Thesis, University of Kiel.

Fischbeck, G., Dennert, J. and Müller, R. (1992). Untersuchungen zur Verwertung des Stickstoffes in der oberirdischen Biomasse von Winterweizen-Feldbeständen beiunterschiedlicher Höhe und Verteilung der mineralischen Dungung. Bayerisches Landwirtschaftliches Jahrbuch 69: 131-148.

Hadas, A., Bar-Yosef, B., Davidov, S. and Sofer, M. (1983). Effect of pelleting, temperature and soil type on mineral nitrogen release from poultry and dairy manures, Soil Sci. Soc. Am. J. 47: 1129-1133.

Loecke, T.D., Liebman, M., Cambardella, C.A. and Richard, T.L. (2004). Corn response to composting and time of application of solid swine manure. Agronomy Journal 96 (1): 214-223.

Ma, B.L., Dwyer, L.M. and Gregorich, E.G. (1999). Soil nitrogen amendments effects on seasonal nitrogen mineralization and nitrogen cycling in maize production Agronomy Journal 91: 1003-1009.

MSTATC (1988). MSTATC Michigan State University, East Lansing, USA.

Oemichen, J. (1986). "Pflanzenproduktion, Band 2: Produktionstechnik", Paul Parey Verlag, Berlin und Hamburg, 151(1): 73-74.

Pagel, H., Enzmann, J. and Mutscher, H. (1982). "Pflanzennährstoffe in tropischen Böden ihre Bestimmung und Bewertung-", VEB Deutscher Landwirtschaftsverlag, Berlin.

Perkins, H.F. and Parker, M.B. (1971). Chemical composition of broiler and hen manures, Georgian Agric. Expl. Sta. Res. Bull. 90.

Quarcoo, A.N.D. (1996). Characterization and decomposition study of poultry manure. BSc. Thesis, University of Science and Technology, Kumasi.
Schachtschabel, P., Blume, H.P., Brümmer, G., Hartge, K-H. and Schwertmann, U. (1992). "Lehrbunch der Bodenkunde", Ferdinand Enke Verlag, Stuttgart.

Schlicting, E. and Blume, H.P. (1966). ' 'Bodekundliches Praktikum', Verlag Paul Parey, Hamburg, 116(2): 137-138.

Schröder, H. (1997). Untersuchungen zur Ertragsbildung und Stickstoffvertwertung von Wintergerstenbeständen in vershiedenen Produktionssystemen. $\mathrm{PhD}$ thesis, University of Kiel.

Schüller, H. (1969). Die CAL - Methode zur Bestimmung des pflanzenverfügbaren Phosphates in Böden, Z. pflanzenernährung und Bodenkunde 123: 48 - 63.

Siegel, R.S., Hafez, A.A.R., Azevedo, J. and Stout, P.R. (1975). Management procedures for effective fertilization with poultry manure, Compost Science 16: 5-9.

Sieling, K., Schröder, H. and Hanus, H. (1998). Mineral and slurry nitrogen effects on yield, $\mathrm{N}$ uptake, and apparent $\mathrm{N}$-use efficiency of oilseed rape (Brassic napus), Journal of Agricultural Science, Cambridge 130: 165-172.

Sillanpää, M. (1982). Micronutrients and the nutrient status of soils: a global study, FAO Soils Bull. 48, Rome.

Sims, J.T. and Wolf, D.C. (1994). Poultry Waste Management: Agricultural and Environmental Issues, Advances in Agronomy 52: 179.

Weil, R.R. and Mughogho, S.K. (2000). Sulfur nutrition of maize in four regions of Malawi, Agronomy Journal 92 (4): 649-656.

Yagodin, B.A. (1984). “Agricultural Chemistry 2”, English Translation, Mir Publ., Moscow, 383 pp. 